\title{
Study of Water-rock Interaction with Hydrochemical and Isotopic Datum in Laizhou Bay
}

\author{
Liu Feng ${ }^{*}$, Ma Fengshan, Guo Jie and Ding Kuo
}

Key Laboratory of Institute Shale Gas and Geoengineering, Institute of Geology and Geophysics, Chinese Academy of Sciences, 100029, Beijing

\begin{abstract}
Water-rock interaction of the groundwater in aquifer system has been analyzed and inferred with hydrochemical and isotopic datum in Laizhou Bay, eastern China. 32 samples of groundwater from three boreholes (96-5\#, 96-6\#, 112$1 \#)$, couples of seawater, saline water, fresh water, surface water and rainfall are obtained in study area for hydrochemical and isotopic analyses. The origin of groundwater is generally concluded by stable isotope $\left(\delta^{18} \mathrm{O}\right.$ and $\left.\delta \mathrm{D}\right)$ and the analytic results of $\mathrm{Na}^{+}, \mathrm{Ca}^{2+}, \mathrm{Mg}^{2+}, \mathrm{Cl}^{-}, \mathrm{SO}_{4}{ }^{2-}, \mathrm{HCO}_{3}{ }^{-}$changing with depth, combined with total dissolved solids (TDS), electrical conductivity (EC), can be apparently proofs for serious water-rock interaction. The conclusion reveals that the origin of 96-5\#, 112-1\# is most likely saline water different from that the groundwater of 96-6\# which is possible originated from fresh water, surface water or mixing of both. Compared the ion content of same borehole at different depth and different boreholes with same depth, the optimal area for building main well and mining area is determined eventually is around 96-5\#.
\end{abstract}

Keywords: Water-rock interaction, hydrochemical and isotopic datum, boreholes, mining area.

\section{INTRODUCTION}

It is significant to understand the mechanism of waterrock interaction in mining area because it greatly changes ion content in the groundwater, reduces the strength of surrounding rocks and relates intimately with life and property security, especially in developed and densely populated place. Various techniques have been used in the study of groundwater movement and its interaction with rock in order to improve security in mining activities. Environmental isotopes and hydrochemical data, combined tightly hydrogeology, geochemistry and geology, have been widely used in studying process of water-rock interaction. Many more papers on water-rock interaction based on isotopic and hydrochemical evidence have been published, such as reported by Frape [1], J.B. Fisher [2], Kronfeld, J [3], Abdelkader, R [4], Adabi, M. H. [5].

Groundwater chemical and isotopic compositions which belong to the same origin, influenced severely by water-rock interaction, are remarkable difference as depth increases. Therefore, the degree of water-rock interaction can be almost determined from the different composition in groundwater. Previous studies indicate that quantities of efficient methods are available and widely applied to actual water-rock interaction problems. The total dissolved solids (TDS), electrical conductivity (EC) and $\mathrm{PH}$ have also been characteristic factors [4], combining environment isotopic and hydrochemical datum, to analyze occurrence process of water-rock

*Address correspondence to this author at the Key Laboratory 0f Institute Shale Gas and Geoengineering, Institute of Geology and Geophysics, Chinese Academy of Sciences, Beijing 100029; E-mail: ??????????????? interaction. The multivariate statistical analysis, based on geochemical and isotopic datum, is adopted to investigate the water-rock interactions and hydrologic mixing in Northeast Tunisia [6] and it is suggested Jurassic limestone suffered from serious water-rock interactions. Stable isotopes, such as ${ }^{18} \mathrm{O}$ and ${ }^{2} \mathrm{H}$ (deuterium, D), as the typical characteristics of groundwater had been already used by James R. O'Neil and Thomas C. Hanks [7] and obtained the evidence about water-rock interactions along the San Andreas and Garlock Faults of California. A. Bath holds that the chemical conditions and rock properties, which is called water-rock interactions, determine the groundwater quality to a great extent [8].

\section{STUDY AREA AND BACKGROUND SETTING}

The study area is located at Northwest of Jiaojia Village, Laizhou Bay, eastern China, from $120^{\circ} 06^{\prime} 46^{\prime \prime} \mathrm{E}$ to $120^{\circ} 10^{\prime} \mathrm{E}$ and $37^{\circ} 23^{\prime} \mathrm{N}$ to $37^{\circ} 26^{\prime} \mathrm{N}$, (Fig. 1) [9]. This paper provides analytic expression the process of water-rock interaction by applying geochemical and isotopic data. Therefore, the distribution, formation and movement of various geologic factors, for example, climate, hydrology, fault, geomorphology and paleogeography, must be investigated clearly. Due to the complicated tectonic movements, the Yi-Shu fault belt is approximately $30 \mathrm{~km}$ from the mining area and the east side is Mou-Ji fault belt, accompanied with small fault fracture (Fig. 2), and the eastern terrain is totally different from the western side. The eastern side is a hilly region, mostly dominated by denudation, with average elevation 40-60m. However, it is pre-mountain alluvial-proluvial plain with lower elevation about $23-25 \mathrm{~m}$ in the western side. The Jiaojia 


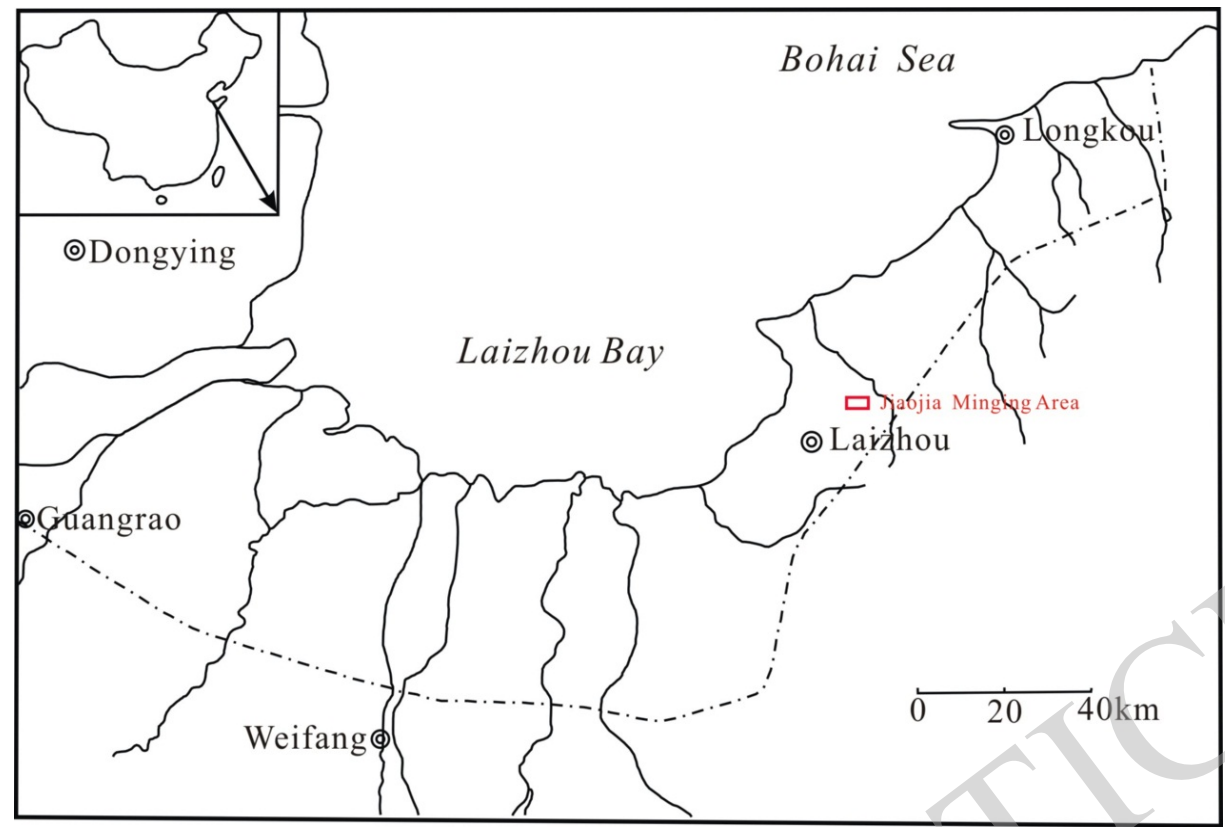

Fig. (1). Map of the Study Area.

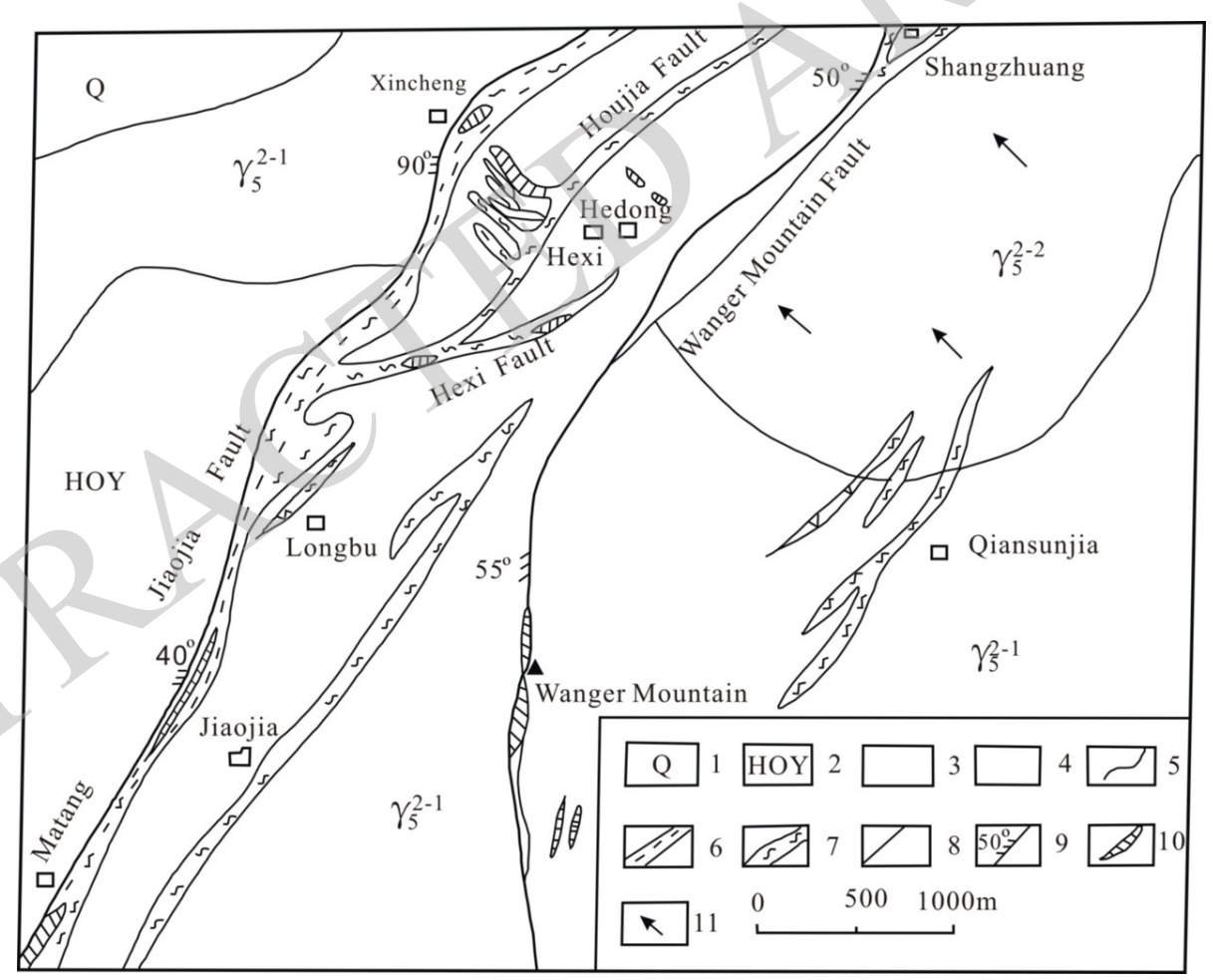

Fig. (2). Small Fault Fracture Around Study Area.

mining area is exactly in the boundary between the hilly region and coastal plain, which suffered from serious erosion and was suitable for gold enrichment. There are three mainly sources of groundwater in Laizhou region: meteoric water, surface water and saline (seawater). According to previous study, the surface water hardly exist except Zhuqiao River and Matang River which are mostly used in irrigation and industrial production. Compared with surface water, the annual average rainfall about $600-700 \mathrm{~mm}$, concentrate in three months (July, August, September), is extremely considerable because of the area of the monsoon climate. The investigation results reveal that three mainly aquifers, quaternary aquifer, phreatic aquifer and confined aquifer, are the basis of water-rock interaction.

The pores and fracture structures are the main place through which groundwater flows. Thus, groundwater flow 
Table 1. Chemical and Isotopic Composition (in mg/l) of Groundwater from 96-5\# Borehole.

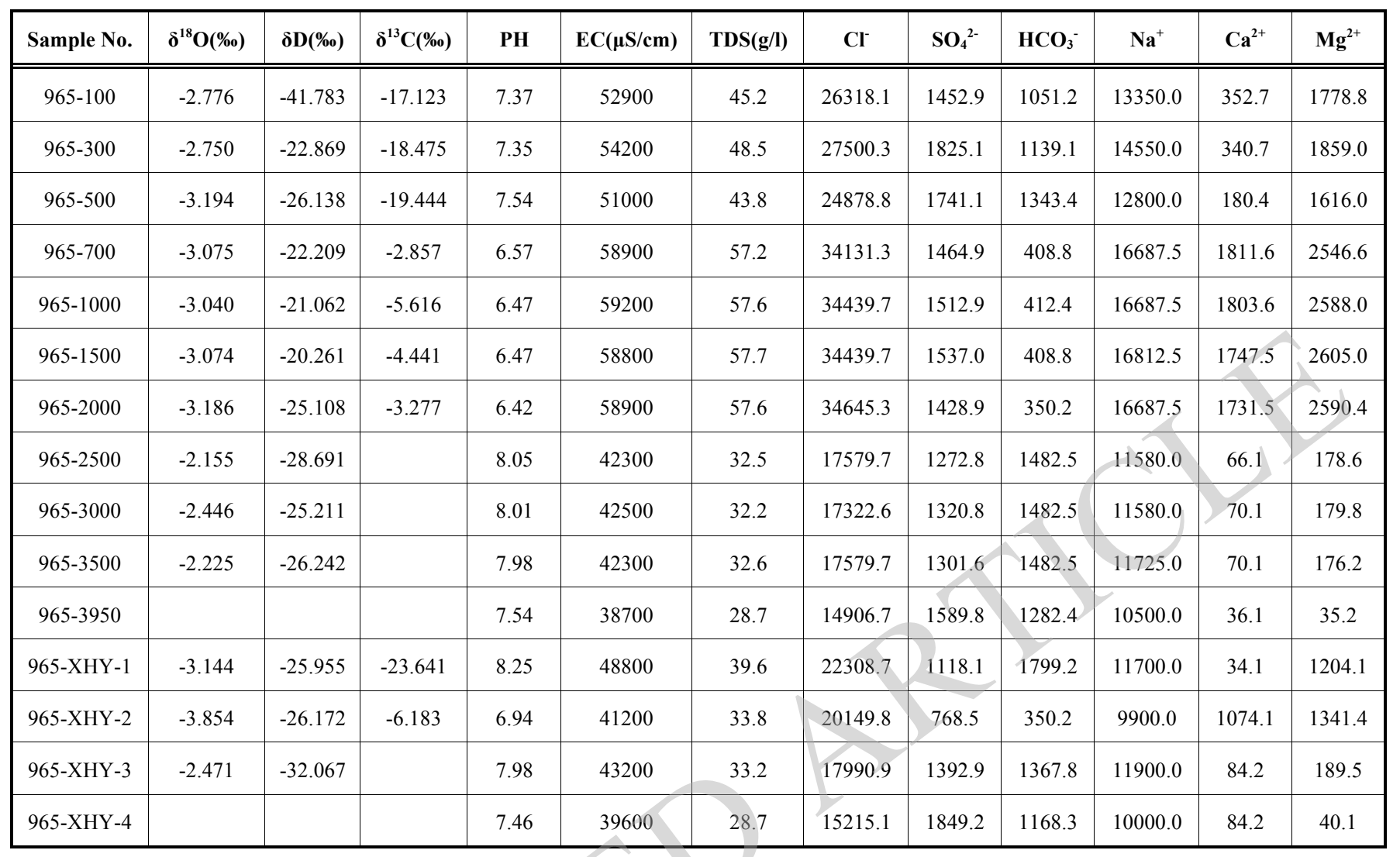

velocity, to a great extent, is influenced by the development degree of void ratio. However, previous studies proved that groundwater flow speed is extremely slow, compared with streams or rivers, in order to provide enough time for the process of water-rock interaction. Jun Liu, Zongyu Chen etc. used chlorofluorocarbons $\left(\mathrm{CFC}_{\mathrm{S}}\right)$ and tritium $\left({ }^{3} \mathrm{H}\right)$ to estimate the groundwater flow velocity in Hohhot Basin, China $[10]$ and it was suggested that the mean regional flow velocity of the shallow groundwater is about $0.73 \mathrm{~km} / \mathrm{a}$. Based on the Darcy's law and field data, namely combined theoretic formulation and practical data, Stephen H.Hall suggested that the groundwater velocity can be equal to $3.0 \mathrm{ft} /$ day [11]. Two characteristics, the changed ion content of groundwater and weakened rocks, can be powerful evidence for the process of water-rock interaction. Tang Liansheng, Wang Sijing implied that rocks strength reduced, even though be destroyed, after water-rock interaction which mainly influenced by $\mathrm{PH}$, hydrolysis, dissolution, ion-exchange action, temperature, pressure [12].

Therefore, the geochemical $\left(\mathrm{Na}^{+}, \mathrm{Ca}^{2+}, \mathrm{Mg}^{2+}, \mathrm{Cl}^{-}, \mathrm{SO}_{4}{ }^{2-}\right.$, $\left.\mathrm{CO}_{3}^{2-}, \mathrm{NO}_{3}^{-}\right)$and isotopic $\left(\mathrm{D},{ }^{18} \mathrm{O}\right)$ datum, combined with other information (PH, EC), can be useful method to prove existence of water-rock interaction and infer strength parameters of surrounding rock and provide a secure exploitation mode to protect life and property from damage.

\section{SAMPLING}

Three boreholes (96-5\#, 96-6\#, 112-1\#) were drilled in order to obtain representative groundwater samples for inter- preting the process of water-rock interaction and determining safety mining conditions in study area. As the depth of drillings increased, two rounds of 32 groundwater samples were collected from 21 discrete intervals in August-September 2011 and August-September 2012. These include 15 samples from 95-5\# borehole, 10 samples from 96-6\# borehole and 7 samples from 112-1\# borehole.

Totally samples from three drillings collected at different depth, which related tightly with lithologic features, were analyzed at Laboratory for Stable Isotope Geochemistry, Institute of geology and Geophysics and Institute of Geology, China Earthquake Administration to obtain isotopic and geochemical datum. $\mathrm{D}$ and ${ }^{18} \mathrm{O}$ were analyzed by the mass spectrometry and the results were expressed as SMOW per mill $(\delta)$ [9]. To deeply analyze the process of water-rock interaction, the hydrochemistry and ion content must be investigated clearly. $\mathrm{PH}, \mathrm{EC}, \mathrm{Cl}^{-}, \mathrm{SO}_{4}{ }^{2-}, \mathrm{HCO}_{3}^{-}, \mathrm{Na}^{+}, \mathrm{Mg}^{2+}$, $\mathrm{Ca}^{2+}$ are also analyzed for the research plan. The result are reported in Table 1, Table 2, Table 3. The sample number 965-100 and 965-XHY-1 represents it is obtained from 96$5 \#$ borehole at approximately $-100 \mathrm{~m}$ depth and liquid circulation, respectively, the rule is suitable for $96-6 \#$ and $112-1 \#$ boreholes as well.

\section{RESULTS AND DISCUSSION}

The datum in Table 1, 2, 3 suggested that $\delta \mathrm{D}$ of groundwater samples from three boreholes was -19.645 to $51.741 \%$ and $\delta^{18} \mathrm{O}-2.155$ to $-8.114 \%$. In addition, seawater, saline water, fresh water, surface water and rainfall samples 


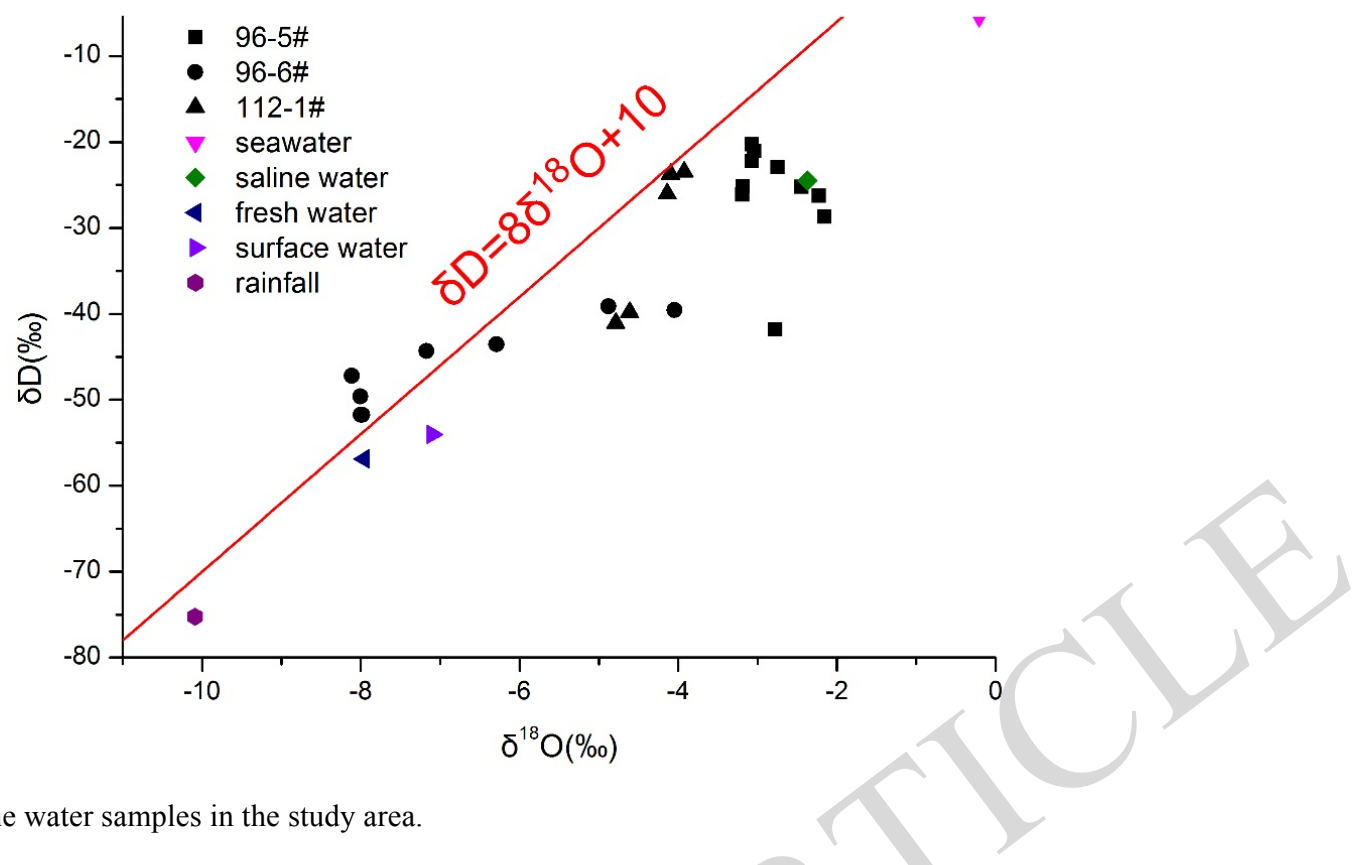

Fig. (3). $\delta^{18} \mathrm{O}$ versus $\delta \mathrm{D}$ for the water samples in the study area

were also collected, analyzed and eventually acquired the value of $\delta^{18} \mathrm{O}$ and $\delta \mathrm{D}$, listed in Table 4 . The average $\delta^{18} \mathrm{O}$ of seawater, saline water, fresh water, surface water and rainfall was $-0.205,-2.370,-7.957,-7.098,-10.090 \%$ and $\delta \mathrm{D}-5.405$, $-24.462,-56.865,-54.040,-75.240 \%$, respectively. Kendall and McDonnell agreed that the origin of groundwater can generally be confirmed by $\delta \mathrm{D}-\delta^{18} \mathrm{O}$, because the stable isotope is simply related with temperature [13]. Therefore, to obtain the origin of groundwater in the study area, diagram (Fig. 3) of relationship about $\delta^{18} \mathrm{O}$ and $\delta \mathrm{D}$ was drawn from the data in Table 1, 2, 3, 4, it can show concretely the groundwater of 96-5\# and 112-1\# more likely originated from saline water, in turn, the groundwater of 96-6\# is possible invaded by fresh water or surface water Compared the origin of 95-5\#, 112-1\# and 96-6\#, it inferred that the crack developed more abundant in 96-6\# borehole, in other words, the 96-6\# was more vulnerable by water inflow and caused enormous loss of life and property. Besides, it was reasonable believe that all the samples should be located in the lower right of the global meteoric water line (GMWL) defined by Kendall and McDonnell [13], because of the evaporation of the saline water or fresh water. There are still some exceptional samples yet located in the left upper from 96-6\# borehole due to the unexpected mixing between the groundwater and surface water or rainfall, but it almost has no effect on the analytic of water-rock interaction.

Based on above analysis which provided strong evidence that the same borehole different depth with the same origin and the ion contents are different in different depth, the degree of water-rock interaction and whether it occurred or not can be distinguished obviously. In addition, the groundwater of 96-5\# and 112-1\# belongs to the same water source, comparing the ions content at the same depth can be a proof to judge the place where the water-rock interaction is more serve and in is helpful to select a relatively safe area for mining activities.
From the analytic datum listed in Table $\mathbf{1}, \mathbf{2}, \mathbf{3}$, the contents of $\mathrm{Cl}^{-}, \mathrm{SO}_{4}^{2-}, \mathrm{Na}^{+}$which dominated the groundwater qualities were increasing or reducing drastically as drilling depth increases. To distinguish the hydrochemistry type and quality of groundwater, the Piper diagram (Fig. 4) usually used to determine the property of groundwater was drawn from Table 1, 2, 3. Although different depth with different ion contents, $\mathrm{Cl}^{-}, \mathrm{SO}_{4}{ }^{2-}, \mathrm{Na}^{+}$contents take account for more than $90 \%$ in almost samples, such as $965-100$ they take account for $90.9 \%$, and the mostly hydrochemistry type is Na$\mathrm{Cl}-\mathrm{SO}_{4}, \mathrm{Na}-\mathrm{Cl}-\mathrm{HCO}_{3}$ or Na-Mg-Cl. The hydrochemistry type, combined with TDS datum in the table, indicates that groundwater in study area hardly flows and is seldom supplied by surface water and meteoric water which provided advantage conditions for water-rock interaction. In order to vividly demonstrate the hydrochemistry type related with property of rock, the diagram (Fig. 5, Fig. 6) of ions content changed with depth is drawn from Table 1, Table 2, Table 3, respectively. With regard to $96-5 \#, 96-6 \#$ and $112-1 \#$ boreholes, the contents of $\mathrm{Na}^{+}, \mathrm{Cl}^{-}, \mathrm{Mg}^{+}, \mathrm{Ca}^{2+}$ changed with better consistent, namely they increase or reduce apparently at the same depth. The regular changing of $\mathrm{HCO}_{3}^{-}$opposites to $\mathrm{Na}^{+}, \mathrm{Cl}^{-}, \mathrm{Mg}^{+}, \mathrm{Ca}^{2+}$, it may be a sign of water-rock interaction, consuming $\mathrm{HCO}_{3}^{-}$, obtaining the other ions. It was easy to observe that the $\mathrm{SO}_{4}{ }^{2-}$ varied extremely irregular with depth increasing and had hardly relative with $\mathrm{Na}^{+}, \mathrm{Cl}^{-}, \mathrm{Mg}^{+}$, $\mathrm{Ca}^{2+}, \mathrm{HCO}_{3}{ }^{-}$, hence $\mathrm{SO}_{4}{ }^{2-}$ can't be characteristic for waterrock interaction in Laizhou Bay area.

Involving the water-rock interaction, lithological characteristics must be investigated immediately to interpret the changing of ions content. For 96-5\#, the groundwater samples were obtained discrete intervals at $100,300,500,700$, $1000,1500,2000,2500,3000,3500,3950 \mathrm{~m}$ and so were the rock specimens. Fig. (5) reveals clearly that at 100, 300, $500 \mathrm{~m}$ the ions content of $\mathrm{Na}^{+}, \mathrm{Cl}^{-}, \mathrm{Mg}^{+}, \mathrm{Ca}^{2+}, \mathrm{HCO}_{3}^{-}$ varied little and the results can be inferred the lithological 
Table 2. Chemical and Isotopic Composition (in mg/l) of Groundwater from 96-6\# Borehole.

\begin{tabular}{|c|c|c|c|c|c|c|c|c|c|c|c|c|}
\hline Sample No. & $\delta^{18} \mathrm{O}(\%)$ & $\delta \mathrm{D}(\%)$ & $\delta^{13} \mathrm{C}(\%)$ & PH & $\mathrm{EC}(\mu \mathrm{S} / \mathrm{cm})$ & $\operatorname{TDS}(\mathrm{g} / \mathrm{l})$ & $\mathrm{Cl}^{-}$ & $\mathrm{SO}_{4}{ }^{2-}$ & $\mathrm{HCO}_{3}^{-}$ & $\mathrm{Na}^{+}$ & $\mathrm{Ca}^{2+}$ & $\mathbf{M g}^{2+}$ \\
\hline $966-100$ & -7.998 & -51.741 & -13.349 & 7.85 & 24700 & 18.1 & 10023.5 & 696.4 & 525.9 & 5425.0 & 969.9 & 383.9 \\
\hline $966-300$ & -8.114 & -47.200 & -13.705 & 7.76 & 24700 & 17.4 & 9972.1 & 720.5 & 379.5 & 5000.0 & 969.9 & 359.6 \\
\hline $966-500$ & -7.980 & -51.734 & -13.556 & 7.82 & 24700 & 18.3 & 9972.1 & 744.5 & 555.2 & 5700.0 & 957.9 & 366.9 \\
\hline $966-700$ & -8.006 & -49.619 & -3.462 & 7.56 & 25900 & 18.0 & 9972.1 & 738.2 & 467.3 & 5450.0 & 953.9 & 366.9 \\
\hline $966-1000$ & -7.170 & -44.291 & -21.967 & 7.5 & 28300 & 19.5 & 9972.1 & 328.1 & 2395.3 & 5900.0 & 360.7 & 437.4 \\
\hline $966-1500$ & -6.290 & -43.528 & -22.166 & 7.51 & 30800 & 21.8 & 11258.9 & 552.3 & 2453.8 & 6489.9 & 320.6 & 607.5 \\
\hline $966-2000$ & -4.048 & -39.558 & & 8.06 & 21200 & 15.1 & 4934.6 & 893.4 & 4045.6 & 4950.0 & 24.0 & 80.2 \\
\hline $966-2700$ & -4.877 & -39.110 & & 8.15 & 21500 & 15.1 & 5140.3 & 446.7 & 4444.6 & 4700.0 & 134.3 & 68.0 \\
\hline 966-ХНY-1 & -7.512 & -51.123 & -14.287 & 7.42 & 26900 & 18.4 & 9972.1 & 792.5 & 817.5 & 5450.0 & 913.8 & 393.7 \\
\hline 966-XНY-3 & -3.615 & -34.849 & & 8.41 & 20700 & 13.9 & 4934.6 & 120. & 4102.9 & 4500.0 & 10.0 & 12.2 \\
\hline
\end{tabular}

Table 3. Chemical and Isotopic Composition (in mg/l) of Groundwater from 112-1\# Borehole.

\begin{tabular}{|c|c|c|c|c|c|c|c|c|c|c|c|c|}
\hline Sample No. & $\delta^{18} \mathrm{O}(\%)$ & $\delta \mathrm{D}(\%)$ & $\delta^{13} \mathrm{C}(\%)$ & PH & $\mathrm{EC}(\boldsymbol{\mu} \mathrm{S} / \mathbf{c m})$ & $\operatorname{TDS}(\mathrm{g} / \mathrm{l})$ & $\mathrm{Cl}^{-}$ & $\mathrm{SO}_{4}{ }^{2-}$ & $\mathrm{HCO}_{3}^{-}$ & $\mathrm{Na}^{+}$ & $\mathrm{Ca}^{2+}$ & $\mathrm{Mg}^{2+}$ \\
\hline $1121-1000$ & -4.098 & -23.699 & -11.871 & 7.56 & 38400 & 29.1 & 13673.1 & 4322.7 & 502.1 & 9287.5 & 400.8 & 631.8 \\
\hline $1121-1500$ & -3.924 & -23.440 & -12.037 & 7.51 & 38600 & 31.1 & 14906.7 & 4610.9 & 615.6 & 9600.0 & 416.8 & 670.7 \\
\hline $1121-2000$ & -4.138 & -25.981 & -12.575 & 7.46 & 38300 & 31.0 & 15101.7 & 4159.4 & 649.8 & 9750.0 & 400.8 & 639.1 \\
\hline $1121-2500$ & -4.612 & -39.788 & & 6.82 & 34900 & 25.8 & 13364.7 & 2641.7 & 433.2 & 7650.0 & 953.9 & 612.4 \\
\hline $1121-2700$ & -4.789 & -41.067 & & 6.64 & 34500 & 25.7 & 13364.7 & 2737.7 & 399.0 & 7550.0 & 921.8 & 607.5 \\
\hline 1121-XНY-1 & -3.184 & -19.645 & -12.585 & 7.61 & 39400 & 31.4 & 14906.7 & 4514.8 & 729.7 & 9800.0 & 400.8 & 729.0 \\
\hline 1121-XHY-2 & -2.557 & -27.712 & & 6.83 & 39200 & 29.6 & 14906.7 & 3314.1 & 626.6 & 9050.0 & 649.3 & 809.2 \\
\hline
\end{tabular}

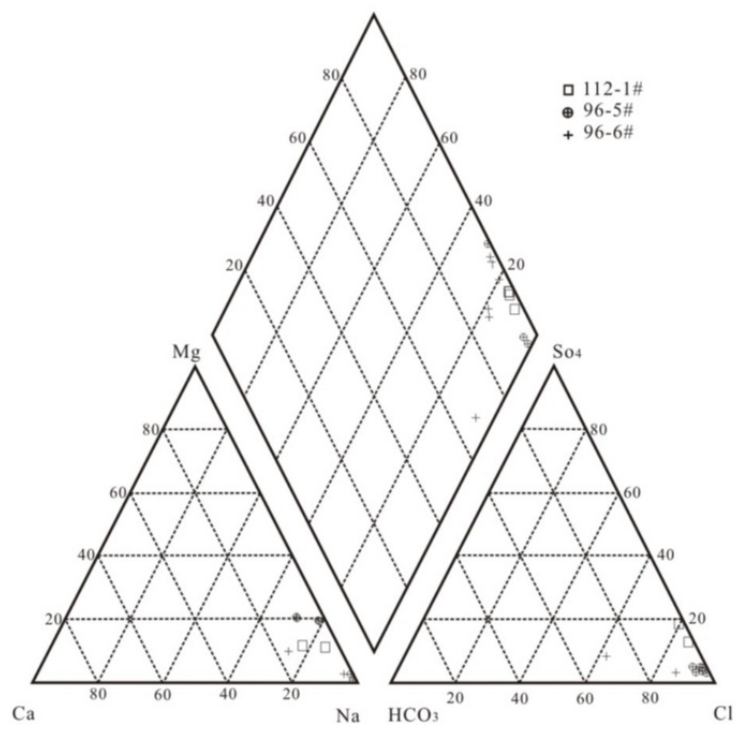

Fig. (4). Piper diagram of groundwater samples from three boreholes in the study area. 
Table 4. Isotopic Compositions of Water Samples in Study Area.

\begin{tabular}{|c|c|c|c|}
\hline Water type & No. & $\delta 180(\%)$ & $\delta \mathrm{D}(\%)$ \\
\hline \multirow{2}{*}{ Seawater } & 1 & -0.181 & -5.180 \\
\hline & 2 & -0.228 & -5.630 \\
\hline \multirow{5}{*}{ Saline water } & 1 & -3.585 & -32.030 \\
\hline & 2 & -2.636 & -25.690 \\
\hline & 3 & -1.850 & -21.070 \\
\hline & 4 & -1.421 & -19.520 \\
\hline & 5 & -2.360 & -24.000 \\
\hline \multirow{4}{*}{ Fresh water } & 1 & -7.543 & -53. \\
\hline & 2 & -8.032 & $-57,820$ \\
\hline & 3 & -7.983 & -57.160 \\
\hline & 4 & -8.269 & -59.040 \\
\hline Surface water & 1 & -7.098 & -54.040 \\
\hline Rainfall & 1 & -10.090 & -75.240 \\
\hline
\end{tabular}
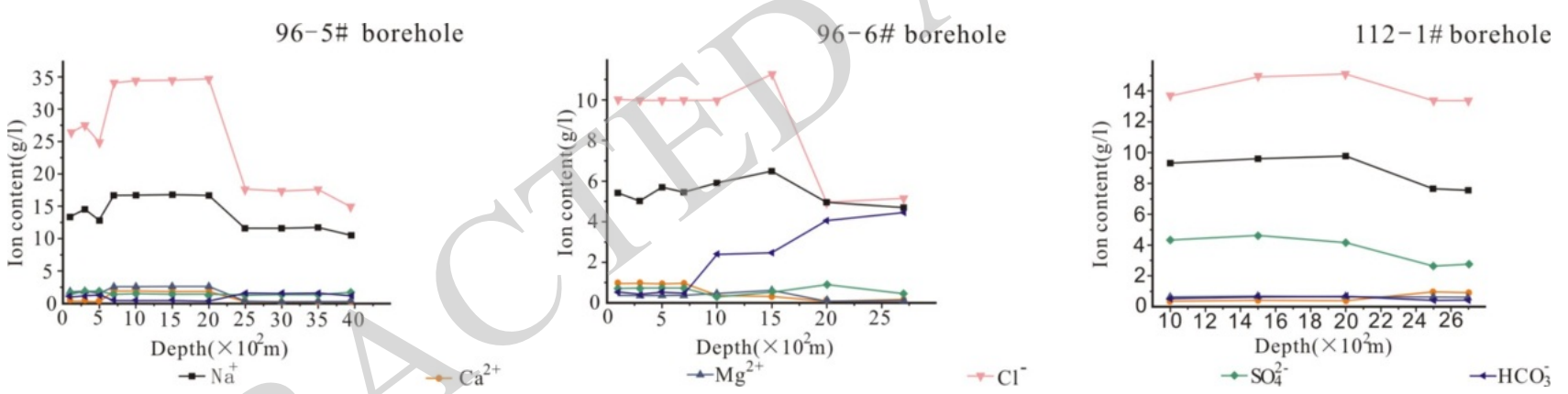

Fig. (5). Distribution of Various Ions with Depth from 96-5\# ,96-6\#,112-1\#Boreholes.

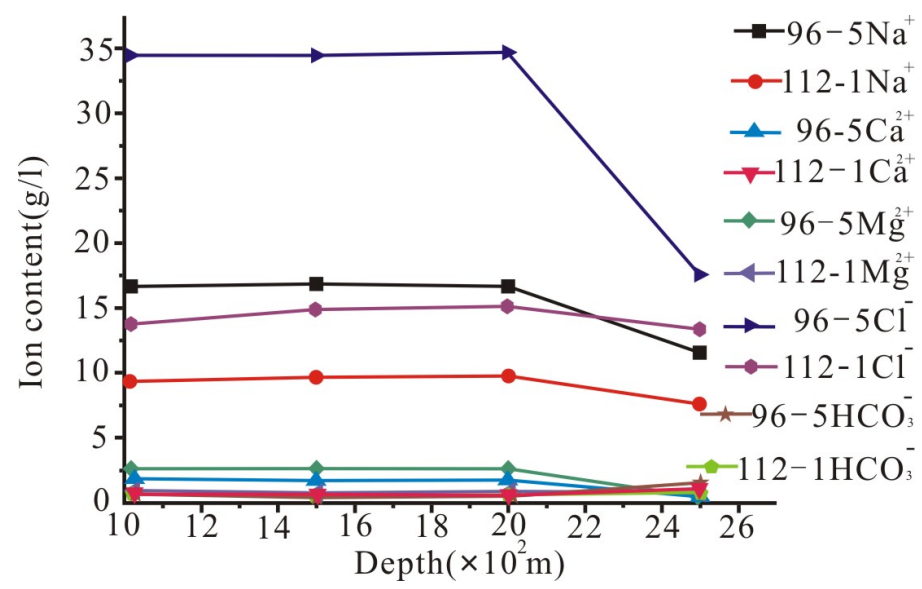

Fig. (6). Ion Content Varies with Depth in 96-5\# and 112-1\# Boreholes. 
characteristic is likely same or similar. Investigation about rock properties indicate that they possess identical characteristic and comprise mainly plagioclase, quartz and biotite. At 700, 1000, 1500, 2000m depth $\mathrm{Na}^{+}, \mathrm{Cl}^{-}, \mathrm{Mg}^{+}, \mathrm{Ca}^{2+}$ increase and $\mathrm{HCO}_{3}{ }^{-}$decrease sharply, it means the water-rock interaction is more serious for the changing of rock properties and the results in this area are biotite adamellite which include $\mathrm{KAlSi}_{3} \mathrm{O}_{8}, \quad \mathrm{NaAlSi}_{3} \mathrm{O}_{8}, \quad \mathrm{CaAl}_{2} \mathrm{Si}_{2} \mathrm{O}_{8}, \quad \mathrm{~K}(\mathrm{Mg}, \mathrm{Fe})_{3} \mathrm{AlSi}_{3} \mathrm{O}_{10}$ $(\mathrm{F}, \mathrm{OH})_{2}$ and is more likely erosion by $\mathrm{HCO}_{3}{ }^{-}$. As for the $2500,3000,3500,3950 \mathrm{~m}$ depth of $95-5 \#$ drilling, the rock is also biotite adamellite which is more difficult to erode because of seriously mylonization. In the same way, the other two pictures in Fig. (5) announced the reason of ions contents changing in 96-6\# and 112-1\# boreholes was partially affected by the surrounding rocks just like 96-5\#. Except for comparison between different depths in the same borehole, the optimum area for the main well can be determined by comparison between different drillings at same depth, such as 1000, 1500, 2000, 2500m of 96-5\# and 112-1\# boreholes with same water source through above analysis. For the purpose of this paper, Fig. (6) which involved $\mathrm{Na}^{+}, \mathrm{Cl}^{-}, \mathrm{Mg}^{+}$, $\mathrm{Ca}^{2+} \mathrm{HCO}_{3}{ }^{-}$from Table $\mathbf{1}, \mathbf{3}$ only was drawn simply and it shows the content of $\mathrm{Na}^{+} \mathrm{Mg}^{+}, \mathrm{Ca}^{2+}$ is higher in 96-5\# than 112-1\# boreholes and the content of $\mathrm{HCO}_{3}{ }^{-}$was lower in 96$5 \#$ than 112-1\# boreholes, namely the water-rock interaction is more serious in 96-5\# area.

Above discussion focus on the hydrochemistry type, the origin of groundwater, the mechanism of water-rock interaction, it is helpful to select a safe area for mining activities.

\section{CONCLUSION}

The geochemical and isotopic methods were effective to judge the origin of groundwater all the time, however it was scarcely applied to analyze the process or the degree of the water-rock interaction. This article concentrates on understanding the possibility of ions contents varying influenced by water-rock interaction and then chooses an optimal place for the main well.

1. The analysis of groundwater samples collected in mining area, Laizhou Bay reveals that the hydrochemistry type is $\mathrm{Na}-\mathrm{Cl}-\mathrm{SO}_{4}, \mathrm{Na}-\mathrm{Cl}-\mathrm{HCO}_{3}$ or $\mathrm{Na}-\mathrm{Mg}$ $\mathrm{Cl}$ and seepage flows and water cycle seldom occur, which provide an ideal environment for sufficient water-rock interaction.

2. The stable isotopes $\left(\delta^{18} \mathrm{O}\right.$ and $\left.\delta \mathrm{D}\right)$ are used to distinguish the origin of groundwater, only related with temperature, and the groundwater of 96-5\#,112-1\# more likely originated from saline water and fresh water or surface water infiltrate into the fracture or leakage of 96-6\# forming groundwater.

3. Compared the origin of 95-5\#, 112-1\# and 96-6\#, it inferred that the crack developed more abundant in 96-6\# borehole, in other words, the $96-6 \#$ is more vulnerable by water inflow and caused enormous loss of life and property. In addition, based on the same

origin of groundwater, similar rock properties and results of ions contents comparing, the hypothesis water-rock interaction in $112-1 \#$ is least serious was proposed.

4. The ion content in different depth is different suggests that the groundwater in different depth never or hardly linked. Although surrounding rock of $96-5 \#$ is eroded more seriouly than 112-1\# at 1000, 1500, $2000,2500 \mathrm{~m}$ depth, the optimal place for main well is around 96-5\# because of more detailed geological, geochemical and isotoptic data. However, special protection measures, such as retaining, must be adopted at $700,1000,1500,2000 \mathrm{~m}$ depth where strength decrease sharply.

\section{CONFLICT OF INTEREST}

The authors confirm that this article content has no conflicts of interest.

\section{ACKNOWLEDGEMENTS}

The research was supported by the National Natural Science Foundation of China (Grant Nos. 41172271, 41372323, 41402280). Grateful appreciation is expressed for these supports.

\section{REFERENCES}

J.C. Vogel, and A. Rosenthal, "Natural Isotopes and Water Stratification in the Judea Group Aquifer (Judean Desert)," Israel Journal of Earth Sciences, vol.39, no.2-4, pp.71-76, 1990.

[4] R. Abdelkader, L. Djabri, H. Rihab, F. Baali, F. Baali, C. Fehdi, and A.Hani, "Geochemical characterization of groundwater from shallow aquifer surrounding Fetzara Lake N. E. Algeria," Arabian Journal of Geosciences, vol.5, no.1, pp.1-13, 2012.

[5] M.H. Adabi, "Application of oxygen \& carbon isotope variations as evidence of water/rock interactions in Renison carbonates," Tasmania, Australia, Water-Rock Interaction, vol. 1, pp. 473-476, 2007.

[6] J.M. S. Trabelsi, S. Bouri, and H. Ben Dhia, "Hydrochemistry of thermal waters in Northeast Tunisia: water-rock interactions and hydrologic mixing," Arabian Journal of Geosciences, 2013.

[7] J.R. Oneil, and T.C. Hanks, "Geochemical Evidence for WaterRock Interaction Along the San-Andreas and Garlock Faults of California," Journal of Geophysical Research, vol.85. no.11, pp. 6286-6292, 1980.

[8] A. Bath, R. Metcalfe, R. McCartney, and P. Degnan, "A. Littleboy, Geochemical indicators of deep groundwater movements at Sellafield, UK," Journal of Geochemical Exploration, vol.90, pp. 2444, 2006

[9] F. Ma, Y. S. Yang, R. Yuan, Z. Cai, and S. Pan, "Study of shallow groundwater quality evolution under saline intrusion with environmental isotopes and geochemistry," Environmental Geology, vol.51, no.6, pp. 1009-1017, 2007. 
[10] J. Liu, Z. Chen, W. Wei, Y. Zhang, Z. Li, F. Liu and H. Guo, "Using chlorofluorocarbons (CFCs) and tritium $(\mathrm{H}-3)$ to estimate groundwater age and flow velocity in Hohhot Basin," China. $\mathrm{Hy}$ drological Processes, vol. 28, no. 3, pp.1372-1382, 2014.

[11] S.H. Hall, S.P. Luttrell, and W.E. Cronin, "A Method for Estimating Effective Porosity and Groundwater Velocity," Ground Water, vol. 29, no. 2, pp. 171-174, 1991.
[12] L. Tang, and S. Wang, "Progress in the study on mechanical effect of the chemical action of water-rock on deformation and failure of rocks," Advance In Earth Sciences, vol. 14, pp. 433-439, 1999.

[13] J. J. McDonnell, and C. Kendall, "Isotope tracers in Catchment Hydrology," Elsevier Science, Amsterdam, vol. 839, pp. 1998.

Received: September 16, 2014

Revised: December 23, 2014

Accepted: December 31, 2014

(C) Feng et al.; Licensee Bentham Open.

This is an open access article licensed under the terms of the Creative Commons Attribution Non-Commercial License (http://creativecommons.org/licenses/by$\mathrm{nc} / 3.0 /$ ) which permits unrestricted, non-commercial use, distribution and reproduction in any medium, provided the work is properly cited. 